TECHNO: JURNAL PENELITIAN

Jurnal homepage: http://ejournal.unkhair.ac.id/index.php/Techno

Volume 07 Nomor 01 Mei 2018

\title{
INVENTARISASI JENIS TANAMAN OBAT TRADISIONAL YANG BERKHASIAT UNTUK PENGOBATAN PENYAKIT KULIT DI BEBERAPA KELURAHAN PULAU TERNATE DAN TERNATE SELATAN
}

\author{
Wirda Az Umagap \\ Dosen Tadris Biologi, IAIN Ternate \\ Email: widhadrakel@gmail.com
}

\begin{abstract}
Abstrak
Pada dasarnya masyarakat Indonesia telah menggunakan pengobatan penyakit kulit dengan cara modern seperti salep, namun dengan cara yang ada belum juga berhasil untuk sembuh. Bahkan membuat si penderita mengeluh dan depresi terhadap penyakit yang dideritanya, sehingga mereka berusaha mencari berbagai macam pengobatan alternatif yang lebih ilmiah dan sederhana seperti pengobatan dengan cara tradisional. Dalam pengobatannya dengan menggunakan tanaman yang berkhasiat obat terutama penyakit kulit dan jenis tanamannya belum banyak diteliti serta belum banyak dikenal oleh masyarakat. Tujuan dalam penelitian ini adalah untuk mengetahui jenis-jenis tanaman tradisional yang berkhasiat untuk pengobatan penyakit kulit. Jenis penelitian ini mengunakan tipe deskriptif yang lokasi penelitiannya dilakukan di kelurahan Sasa, Jambula dan Kastela, Kota Ternate. Sampelnya adalah semua jenis tanaman yang berkhasiat untuk pengobatan penyakit kulit yang telah terinventarisasi. Pengumpulan data dilakukan dengan mengunakan sistem jelajah atau eksplorasi dengan analisis datanya dengan menggunakan data primer dan data sekunder. Berdasarkan hasil penelitian bahwa jenis tanaman yang berkhasiat untuk pengobatan penyakit kulit yang telah terinventarisasi dengan menggunakan tehnik jelajah yang ditemukan di kelurahan Sasa, Jambula, dan Kastela berjumlah 15 jenis tanaman dengan 11 famili yang dipakai dalam pengobatan penyakit kulit. Dari hasil wawancara bahwa cara pengolahan jenis tanaman tersebut ada yang ditumbuk, diiris-iris, dan dipotong-potong lalu dioleskan ke bagian yang sakit. Masyarakat setempat lebih cenderung menggunakan jenis tanaman tersebut sebagai obat tradisional untuk pengobatan penyakit kulit.
\end{abstract}

Kata Kunci: Inventarisasi, tanaman obat, pengobatan alternatif, penyakit kulit

\section{PENDAHULUAN}

Kota Ternate adalah sebuah kota yang berada di bawah kaki gunung api Gamalama pada sebuah Pulau Ternate di Provinsi Maluku Utara, Indonesia. Ternate merupakan Ibu Kota sementara Provinsi Maluku Utara secara de facto dari tahun 1999 hingga 2010. Pada tanggal 4 Agustus 2010, Sofifi diresmikan menjadi ibukota pengganti Ternate. Kota Ternate merupakan Kota Kepulauan yang memiliki luas wilayah $547,736 \mathrm{~km}^{2}$, dengan 8 pulau, yakni; Pulau Ternate, Pulau Hiri, Pulau Moti, Pulau Mayau, Pulau Tifure, Pulau Maka, Pulau Mano, dan Pulau Gurida (Pulau berukuran kecil yang tidak berpenghuni). Pulau Ternate merupakan Pulau yang terdiri dari beberapa kelurahan diantaranya adalah Ake Taduma, 
Bula, Dorpedu, Foramadiahi, Jambula, Kastela, Kulaba, Loto, Rua, Sulamadaha, Takome, Tobololo, Togafo, Tabona, dan Ternate Selatan merupakan Kota Ternate yang terdiri dari beberapa kelurahan juga yaitu; Ngade, Fitu, Gambesi, Sasa, Bastiong Karance, Bastiong Talangame, Jati, Jati Perumnas, Kalumata, Kayu Merah, Mangga Dua, Mangga Dua Utara, Tabona, Tanah Tinggi, Tanah Tinggi Barat, Toboko, dan Ubo-Ubo (Jafar, 2010).

Dari banyaknya pulau-pulau, dapat terlihat bahwa tanah yang subur sangat baik untuk ditumbuhi berbagai jenis tanaman. Jenis-jenis tanaman tersebut diantaranya juga dapat dipergunakan oleh masyarakat sebagai tanaman obat-obatan. Dikalangan masyarakat tersebut dikenal dengan tanaman obat tradisional. Jenis-jenis tanaman yang dijadikan sebagai tanaman obat-obatan yang digunakan untuk pengobatan berbagai macam penyakit yang terjadi di masyarakat pada umumnya. Jenis-jenis penyakit yang diobati secara tradisional, salah satu diantaranya adalah jenis penyakit kulit.

Kulit merupakan organ yang terletak paling luar dari permukaan tubuh. Pada kulit yang sehat dapat menjadi cermin bagi seseorang terhadap kesehatan dan pola hidupnya. Selain itu, kulit juga merupakan bagian tubuh yang terpenting, diantaranya sebagai pelindung tubuh dan indera perasa karena kulit merupakan bagian tubuh yang pertama terkena bila ada gangguan atau rangsangan luar (Gunawan, 1990). Ada beberapa faktor yang menjadi penyebab kerusakan kulit, yaitu: iklim, lingkungan, tempat tinggal, kebiasaan yang kurang sehat, kosmetik dan tanaman berbulu. Oleh karena letaknya ada dipermukaan tubuh, maka kulit merupakan bagian tubuh yang pertama terkena pengaruh tidak menguntungkan dari lingkungan luar. Dengan demikian dalam menjaga kulit sama seperti menjaga bagian tubuh yang lain (Gunawan, 1990).

Kulit berfungsi untuk melindungi permukaan tubuh dan merupakan pembungkus elastic yang melindungi tubuh dari pengaruh lingkungan. Selain sebagai pelindung, kulit juga berfungsi untuk menjaga masuknya benda-benda asing dari luar dan dapat melindungi pengaruh buruk oleh ultra violet. Secara umum gejala yang ditimbulkan dari penyakit kulit adalah disebabkan diantaranya kebersihan badan yang tidak bersih terasa gatal apabila digaruk-garuk dan dapat menimbulkan radang luka, akibatnya dari bibit yang disebabkan oleh jamur, bakteri atau mikroorganisme lain yang mudah masuk.

Gangguan kulit biasanya dimulai dengan rasa gatal yang bisa saja hilang, tetapi ada juga yang berhari-hari bahkan bertahun-tahun. Bagian kulit yang gatal biasanya digaruk-garuk oleh si penderita. Kebiasaan ini kurang menguntungkan bagi kesehatan kulit. Gangguan pada kulit dapat meningkat menjadi penyakit yang dapat mengganggu seseorang, oleh sebab itu gangguan penyakit kulit tersebut diantaranya seperti Borok, Luka digigit serangga, Luka berdarah, Luka terbakar, Bisul, Cacar air, Panu, Jerawat, Eksim, Gatal-gatal, Kudis, kurap, dan Belak (pecah-pecah) (Wiryohadikusumo, 1999).

Tanaman yang berkhasiat obat tradisional banyak diketahui secara empiris saja, artinya tanaman tersebut dapat dikelola, digunakan dan dimanfaatkan sebagai pengobatan tradisional (Mamahani and Simbala 2016; Tamalene et al. 2016). Jenis tanaman yang digunakan sebagai obat tradisional mempunyai aktivitas biologi karena mengandung senyawa kimia yang dapat mempengaruhi sel-sel hidup suatu organisme. Biasanya bahanbahan baku untuk pengobatan penyakit kulit digunakan dalam bentuk yang segar dan kering. 
Secara umum masyarakat Indonesia telah menggunakan pengobatan penyakit kulit dengan cara moderen seperti salep, namun dengan cara itu belum berhasil untuk sembuh. Bahkan membuat si penderita mengeluh dan depresi terhadap penyakit yang dideritanya, sehingga mereka berusaha untuk mencari berbagai macam pengobatan alternative yang lebih ilmiah dengan cara tradisional. Pengobatan secara tradisional dengan menggunakan jenis tanaman yang berkhasiat untuk obat penyakit kulit belum banyak yang diteliti, bahkan jenis tanaman tersebut belum banyak dikenal oleh masyarakat. Pengelolaannya dengan cara direbus, dihaluskan lalu air perasannya diminum (Tampubolon, 1995).

Penelitian ini dibatasi pada 3 kelurahan yang ada di pulau Ternate, yakni; Kelurahan Sasa (Kecamatan Ternate Selatan), Kelurahan Jambula dan Kastela (kecamatan Pulau Ternate). Permasalahan yang diangkat dalam penelitian ini adalah jenis tanaman apa sajakah yang digunakan sebagai obat tradisional masyarakat yang berkhasiat untuk mengobati penyakit kulit di Kelurahan Sasa, Jambula, dan Kastela. Tujuan penelitian ini adalah untuk mengetahui jenis tanaman obat tradisional yang berkhasiat untuk pengobatan penyakit kulit di Kelurahan Sasa, Jambula, dan Kastela.

\section{METODE PENELITIAN}

Jenis penelitian ini adalah penelitian Deskriptif yang dilakukan melalui survei dan wawancara. Lokasi Penelitian dilakukan di Tiga Kelurahan Sasa, Jambula dan Kastela, serta dilaksanakan selama 10 hari. Populasi dalam penelitian ini adalah semua jenis tanaman yang berkhasiat obat tradisional untuk pengobatan penyakit kulit di Kelurahan Sasa, Jambula dan Kastela. Sampel dalam penelitian adalah semua jenis tanaman yang berkhasiat untuk pengobatan penyakit kulit di Kelurahan Sasa, Jambula dan Kastela yang terinventarisasi dan diambil bagian-bagian tertentu yang produktif untuk dicandra. Pengumpulan data dilakukan dengan wawancara dan metode jelajah atau eksplorasi di Kelurahan Sasa, Jambula, dan Kastela. Hasil wawancara dengan masyarakat (penyehat tradisional / hattra), dilanjutkan dengan meninjau lokasi tempat tanaman berada. Untuk tujuan identifikasi, bagian tanaman diambil sebagai sampel, dan dibawa ke laboratorium sains IAIN Ternate dan diidentifikasi secara kualitatif. Analisis data dilakukan dengan menggunakan data primer dan data sekunder bersifat kualitatif.

\section{HASIL DAN PEMBAHASAN}

Hasil inventarisasi jenis tanaman yang berkhasiat untuk pengobatan penyakit kulit di tiga kelurahan berdasar hasil wawancara dan survei ditemukan sebanyak 15 jenis dan 11 famili diantaranya adalah Kelapa (Cocos nucifera) berjumlah 767, Jambu Biji (Pisidium Guajava) berjumlah 232, Pepaya (Carica papaya) berjumlah 207, Tapak Darah (Cartharanthus resus L.) berjumlah 202, Kunyit (Curcuma domestica) berjumlah 164, Jahe (Zinger offinale rocs) berjumlah 142, Lengkuas (Languas galanga) berjumlah 139, Nangka (Artocarpus heterophyllus) berjumlah 110, Kamboja (Plumeria acuminate) berjumlah 66, Sirih (Piper betle L.) berjumlah 48, Tomat (Lycopersicon esculentum mill) berjumlah 33, Lidah Buaya (Aloe vera L.) berjumlah 24, Asam Jawa (Tamarindus indica) berjumlah 17, Sidaguri (Sida rhomdifolia L.) berjumlah 12, Kecubung Hutan (Brugmansia suaveokens) berjumlah 3. Sedangkan Famili Arecaceae, Myrtaceae,

Caricaceae, Apocynaceae, Zingiberaceae, Moraceae, Piperaceae, Solanaceae, Liliaceae, Caesalpiniceae, Malvaceae. 


\section{Asam Jawa (Tamarindus indica)}

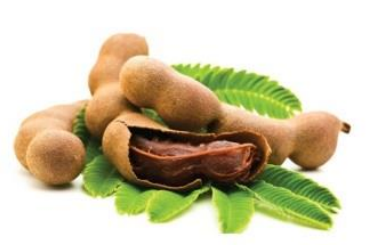

Famili Caesalpiniciaceae, memiliki tempat tumbuh lebih banyak ditemukan ditepi jalan sebagai pohon pelindung dan ditanam didaerah perkampungan sebagai pohon buah. Tanaman ini memiliki habitus pohon dengan daun yang rindang bersirip genap, bentuk bulat panjang, dan bunganya berwarna kuning. Buahnya polong, bertangkai, bulat panjang pipih, biji agak gepeng dan berwarna hitam. Sumber Gambar: http://travel.tribunnews.com

Berkhasiat untuk pengobatan penyakit Borok (luka nanah). Bagian tanaman yang digunakan adalah biji asam jawa. Cara pengolahannya yaitu biji asam jawa sebanyak 2 siung ditumbuk halus kemudian ditaburkan pada kulit yang luka (bernanah), lalu dibalutkan selama 2-1 kali sehari.

\section{Jahe (Zinger offinale rocs)}

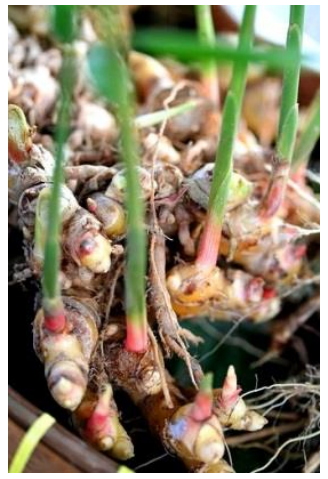

Famili Zingiberaceae, menyukai tanah yang sedikit berlembab, tetapi cukup akan sinar matahari dan tanaman ini juga tidak tumbuh liar tetapi sering ditanam oleh masyarakat. Daerah tempat tumbuhnya adalah di dataran rendah dan di daerah pegunungan. Tanaman ini berbatang basah, tingginya mencapai $60 \mathrm{~cm}$ tegak, akarnya berbentuk rimpang bercabang, berserat kasar, menjalar mendatar, bagian dalamnya berwarna kuning pucat. Berkhasiat untuk pengobatan penyakit Luka digigit serangga. Bagian tanaman yang digunakan adalah rimpang jahe.

Sumber Gambar: dokumentasi pribadi

Cara pengelolaannya yaitu rimpang jahe sebanyak 1 siung ditumbuk dan dicampuri dengan garam secukupnya, setelah itu dioleskan ke kulit yang sakit selama 1-2 kali sehari.

\section{Jambu Biji (Pisidium guajava)}

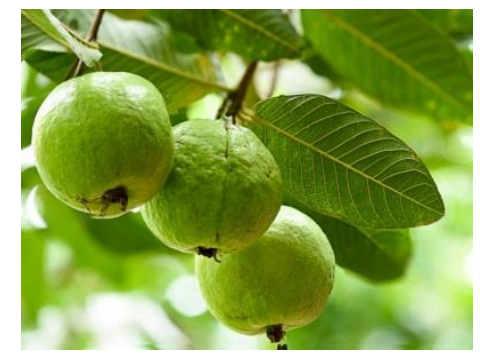

Famili Myrtaceae, banyak tumbuh di tanah yang gembur dan dapat ditanam di halaman/pekarangan, tanah berbatu-batu maupun di tempat yang terbuka dan bamyak air/lembab. Daerah tempat tumbuhnya di dataran rendah. Tanaman ini merupakan jenis perdu yang mempunyai banyak cabang, batangnya keras, berwarna coklat mengkilap yang kulitnya mudah terkelupas. Daunya berbentuk bulat telur, kasar lagi kusam. Bunganya berwarna putih dan buahnya berisi biji.

Sumber Gambar: dokumentasi pribadi

Jambu biji berkhasiat untuk pengobatan penyakit luka bakar. Bagian tanaman yang digunakan adalah daun dan biji. Cara pengelolaannya yaitu beberap daun jambu biji dilumatkan atau ditumbuk hingga halus lalu ditempelkan pada tempat yang sakit selama 1-3 kali sehari. 


\section{Kunyit (Curcuma domestica)}

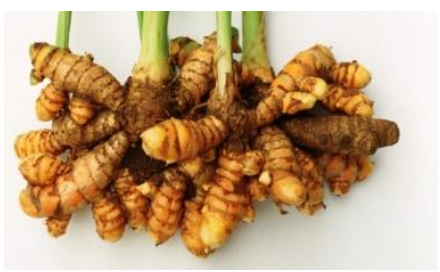

Sumber Gambar: www.klik.riau.com

Famili Zingiberaceae, tumbuh secara liar di hutan kecil atau bekas kebun dan sering ditanam masyarakat dipekarangan atau halaman. Daerah tempat tumbuh pada dataran rendah dan dataran tinggi. Tanaman ini memiliki tinggi mencapai $40-100 \mathrm{~cm}$. Tanaman ini tidak mempunyai bulu, berwarna hijau, bunganya pucat dan pangkalnya berwarna kuning.

Daunnya berbentuk telur memanjang sedangkan akarnya berupa rimpang dan dagingnya berwarna kuning tua. Berkhasiat untuk pengobatan penyakit cacar air. Bagian tanaman yang digunakan adalah rimpang kunyit. Cara pengolahannya adalah rimpang kunyit sebanyak 1 siung dicampur dengan asam dan minyak kelapa secukupnya setelah itu dioleskan pada kulit yang terkena cacar air selama 1-3 kali sehari.

\section{Kelapa (Cocos nucifera)}

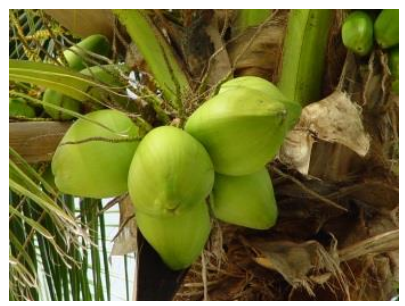

Famili Areacaceae/palmae, banyak tumbuh di tepi pantai pada tanah yang berpori, kaya humus dan berbuah serta ada juga yang ditanam di kebun. Daerah tempat tumbuh pada dataran tinggi. Tanaman ini berpohon besar pada bagian pangkalnya, batangnya ramping, tegak lurus tidak bercabang dengan bekas daun yang keras, daun majemuk menyirip, tumbuh berkumpul, diujung batang membentuk roset batang.

Sumber Gambar: dokumentasi pribadi

bunga kecil-kecil berwarna kuning putih berkelamin tunggal terdapat dalam satu pohon yang tersusun didalam karangan berupa tongkol yang bercabang dikelilingi oleh seludung bunga. Buahnya buah batu berbiji satu, berbentuk bulat telur sungsang, terbungkus serabut tebal dengan kulit dalamnya keras seperti tulang, berisi air dan dagingnya mengandung santan. Berkhasiat untuk pengobatan penyakit kurap, kudis, dan radang kulit. Bagian tanaman yang digunakan adalah buah kelapa (minyak kelapa). Cara pengelolaannya adalah buah kelapa diolah menjadi minyak kelapa kemudian diperlukan sebanyak 1 sendok makan dan kapur sirih secukupnya setelah itu diaduk rata seperti salep setelah dioleskan ke kulit yang sakit selama 1-3 kali sehari.

\section{Kamboja (Plumeria acuminate)}

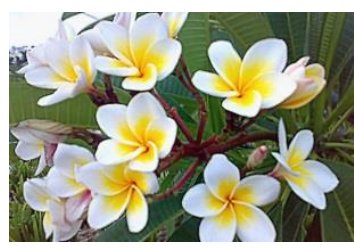

Famili Apocyceae/palmae, banyak tumbuh diperkebunan dan tumbuh di semua keadaan tanah baik basah maupun kering serta dapat ditanam sebagai tanaman liar. Daerah tempat tumbuh pada dataran rendah. Tanaman ini berupa pohon yang kecil yang memiliki banyak cabang. Batangnya bengkok sedangkan cabang-cabang mudahnya lunak dan Sumber Gambar: dokumentasi pribadi terdapat totol-totol.

Daunnya rata dengan ujung dan pangkalnya menajam. Bunganya berwarna merah atau tengahnya kuning, sedangkan bau bunganya harum. Berkhasiat untuk pengobatan penyakit 
bercak (pecah-pecah pada telapak kaki). Bagian tanaman yang digunakan adalah kulit batang. Cara pengelolaannya adalah kulit batang 1 tangkai ditumbuk dan dicampur air, lalu diperas setelah itu perasaannya di minum selama 1-2 kali sehari.

\section{Kecubung Hutan (Brugmansia suaveokens)}

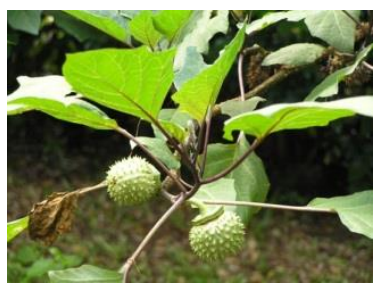

Famili Solanaceae, tumbuh ditempat terbuka maupun terlindungi, sering tumbuh liar sebagai semak di hutan kecil atau bekas hutan. Daerah tempat tumbuh di dataran tinggi. Tanaman ini merupakan tanaman perdu yang tumbuh tegak, batangnya banyak memiliki cabang. Daunnya berbentuk corong, lebar dengan tangkai yang panjang.

Sumber Gambar: http:/ / wit2an.blogspot.com

Bunganya muncul pada ujung-ujung tangkai, berbentuk mempunyai corong tunggal dan menggantung. Buahnya berbentuk bulat, buah batu yang diselubungi oleh bulu-bulu yang lembut dan berduri didalamnya terdapat biji yang banyak. Berkhasiat untuk pengobatan penyakit eksim. Bagian tanaman yang digunakan adalah buah kecubung hutan. Cara pengelolaannya adalah buah kecubung hutan 1 buah diiris dan dicampurkan dengan pinang, sirih dan kapur lalu dioles ke kulit yang sakit secara merata selama 1-2 kali sehari. Sebelum diobati eksim tersebut dibersihkan dengan air panas terlebih dahulu.

\section{Lengkuas (Languas galanga)}

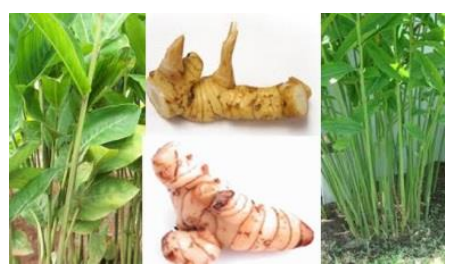

Famili Zingiberaceae, menyukai tanah gembur yang terlindung dari sengatan matahari, sedikit lembab tapi tidak tergenang air dan banyak juga ditanam orang dipekarangan sebagai dapur hidup (bumbu) dan juga obat-obatan. Daerah tempat tumbuh pada dataran rendah. Tanaman ini berbatang semu terdiri dari helaian daun.

Sumber Gambar: http://darsatop.lecture.ub.ac.id

Bentuk daunnya bulat panjang dan pelepahnya menyelubungi seluruh batang mengkilap, ujungnya meruncing warnanya hijau mengkilap. Akarnya berbentuk rimpang, kulitnya merah, memiliki serat lebih keras dan rasanya pedas. Berkhasiat untuk pengobatan penyakit panu. Bagian tanaman yang digunakan adalah rimpang lengkuas. Cara pengelolaannya rimpang lengkuas sebanyak 1 siung ditumbuk halus dan dicampur garam secukupnya, kemudian digosokkan pada kulit yang sakit selama 1-2 kali sehari.

\section{Lidah Buaya (Aloevera L.)}

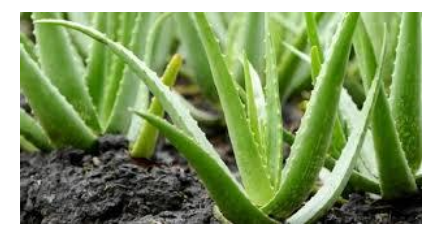

Famili Liliaceae, menyukai daerah yang berhawa panas dan terbuka dengan kondisi tanah yang gembur, tanaman ini juga tidak menyukai tampat yang tergenang air karena batangnya dapat membusuk, serta tanaman ini dapat disebut sebagai tanaman yang mengandung air (sekulen).

Sumber Gambar: dokumentasi pribadi 
Daerah tempat tumbuh pada dataran rendah. Tanaman ini berdaun basah, berbentuk panjang, ujungnya runcing berwarna hijau, mengandung lendir dan tepi berduri, bunganya berwarna jingga dengan tangkai yang panjang, keluar bila sudah tua. Akarnya berserabut. Berkhasiat untuk pengobatan penyakit bisul. Bagian tanaman yang digunakan adalah daging daun lidah buaya. Cara pengelolaanya adalah daging daun lidah buaya dicampur dengan garam secukupnya lalu dilumatkan hingga rata. Kemudian ditempel pada bisul selama 1-3 kali sehari.

10.Nangka (Arthocarpus heterophyllus)

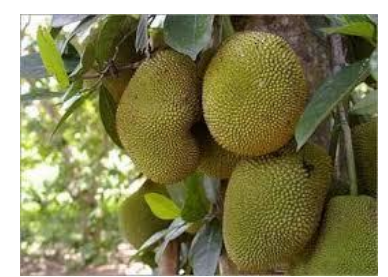

Famili Meraceae, biasanya tumbuh liar di hutan-hutan tetapi ada juga yang ditanam orang dipekarangan atau dihalaman rumah sebagai pohon buah-buahan serta tumbuh di tempat yang tidak tergenang air. Daerah tempat tumbuh di dataran rendah. Tanaman ini berupa pohon kecil bergetah, berbuah terus-menerus.

Sumber Gambar: dokumentasi pribadi

Daunnya tebal seperti kulit, letaknya berseling, helaian daunnya memanjang atau bulat telur sungsang tapi, kadang berkeluk, ujungnya meruncing, pangkal menyempit, permukaan atasnya mengkilat warnanya hijau tua. Buahnya besar bergantung pada batang dan cabang berbentuk memanjang atau berbentuk ginjal, berkulit tebal dengan berduri tempel pendek, berbentuk piramin, warnanya hijau kekuningan, daging buah tebal berwarna kuning, didalamnya ada biji berbentuk lonjong. Berkhasiat untuk pengobatan penyakit luka terpukul. Bagian tanaman yang digunakan adalah daun nangka. Cara pengolahannya adalah daun yang kering digiling halus menjadi bubuk setelah itu dibubuhkan ketempat yang sakit selama 1-2 kali sehari.

\section{Pepaya (Carica papaya L.)}

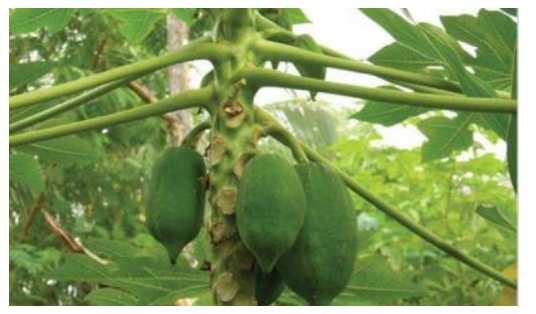

Famili Cariccaceae, banyak ditanam di halaman dan kebun sebagai pohon buah-buahan. Daerah tempat tumbuh pada dataran rendah dan dataran tinggi. Tanaman ini berupa semak berbentuk pohon, bergetah, tumbuh tegak, batangnya bulat berongga, dibagian atas kadang cabang, kulit batang terdapat tanda bekas tangkai daun yang telah lepas.

Sumber Gambar: dokumentasi pribadi

Daunnya berkumpul diujung batang dan ujung percabangan, tangkainya bulat selindris berongga, helaian daun berbagi menjari, ujungnya runcing, pangkalnya berbentuk jantung, warnanya hijau. Bunga mahkota berbentuk terompet, warnanya putih kekuningan. Buah seperti buah buni yang bisa bermacam-macam baik bentuk, warna, dan daging buahnya. Bijinya banyak berwarna hitam dan diselimuti selaput tipis. Berkhasiat untuk pengobatan penyakit jerawat. Bagian tanaman yang digunakan adalah bunga papaya. Cara pengolahannya adalah bunga papaya yang kering dicampur beras kemudian digiling atau ditumbuh halus setelah itu dibubuhi atau dioleskan kekulit yang sakit selama 1-2 kali sehari. 


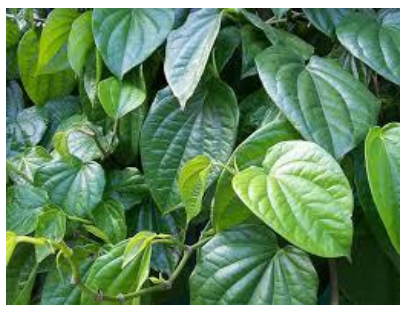

Famili Piperaceae, sering menyukai tempat yang terbuka atau sedikit terlindung dan ada rambatannya. Daerah tempat tumbuh pada dataran rendah. Tanaman ini merupakan tanaman yang merambat pada pohon yang tumbuh disekitarnya. Batangnya berwarna hijau kecoklatan, berbentuk jantung, agak kasar bila diraba, berwarna hijau tua. Bunganya tersusun dalam bulir merunduk.

Sumber Gambar: dokumentasi pribadi

Buahnya bulat berdaging, berwarna hijau. Berkhasiat untuk pengobatan penyakit gatal-gatal atau koreng. Bagian tanaman yang digunakan adalah daun sirih. Cara pengolahannya adalah daun sirih sebanyak lima helaian ditambah air secukupnya untuk direbus hingga mendidih lalu didiamkan agar dingin, setelah itu dibilas pada kulit yang gatal selama 1-2 kali sehari.

\section{Sidaguri (Sida rhomdifolia L.)}

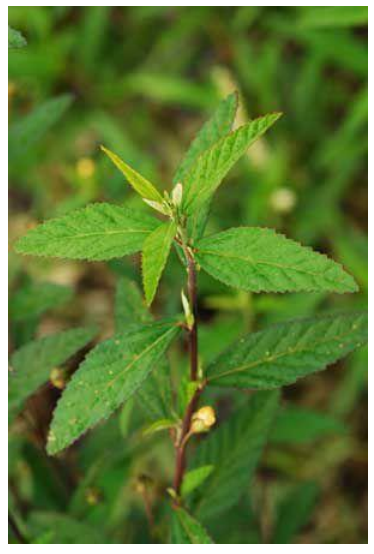

Famili Malvaceae, banyak tumbuh liar di semak, dipinggir jalan, dihutan, dan ditempat yang tidak terkena sinar matahari cerah atau sedikit terlindung. Daerah tempat tumbuh pada dataran rendah. Tanaman ini termasuk tanaman perdu tegak yang banyak bercabang dengan cabang kecil berambut ratap. Daunnya berbentuk bulat memanjang atau bentuknya lansep yang letaknya berseling, tepi bergerigi, ujung runcing, tulang daun menyirip. Bunganya tunggal berwarna kuning cerah, akar dan kulit sidaguri kuat. Berkhasiat untuk pengobatan penyakit luka disengat serangga. Bagian tanaman yang digunakan adalah bunga sidaguri. Cara pengolahannya adalah 15 biji bunga sidaguri dilumatkan hingga halus setelah itu dioleskan secara merata pada luka selama 1-2 kali sehari.

Sumber Gambar: https:/ /www.utakatikotak.com

\section{Tapak Dara (Cartharanthus resus L.)}

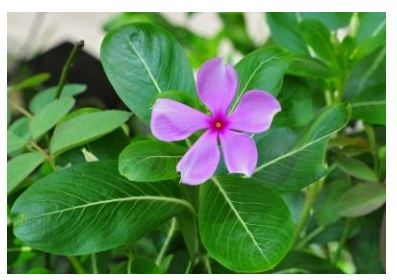

Famili Apocynaceae, banyak tumbuh ditempat yang agak terlindung maupun terbuka. Daerah tempat tumbuh pada dataran rendah. Tanaman ini merupakan tumbuhan semak yang tidak terlalu besar. Batangnya tumbuh tegak dan bercabang banyak. Bunganya berwarna merah keunguan dan ada yang putih berdaun bulat telur tersusun, berhadapan berwarna hijau tua, mengkilat dan agak tebal.

Sumber Gambar: dokumentasi pribadi

Buahnya merupakan buah bumbung berbuluh yang berisikan banyak biji berwarna hitam. Berkhasiat untuk pengobatan penyakit luka bakar. Bagian tanaman yang digunakan adalah daun tapak dara. Cara pengolahannya adalah beberapa helai daun tapak dara ditumbuk hingga halus lalu tempelkan pada luka yang sakit selama 1-2 kali sehari. 


\section{Tomat (Lycopersicon esculentum Mill.)}

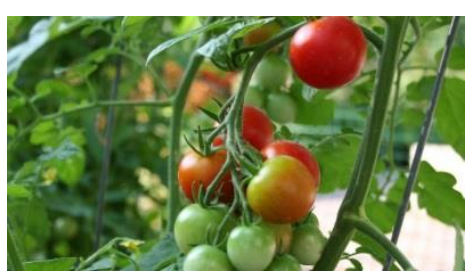

Famili Solanaceae, biasanya tumbuh ditempat yang gembur dan subur serta tidak tahan akan hujan dan sinar matahari yang terik. Ditanam orang sebagai tanaman buah diladang dan dipekarangan. Daerah tempat tumbuh pada dataran rendah. Tanaman ini tumbuh tegak, sering bercabang banyak, berambut dan berbau kuat.

Sumber Gambar: dokumentasi pribadi

Batangnya bulat menebal pada buku-buku, teraba kasar dan rapuh. Daunnya majemuk bersirip selang seling. Bentuk bulat telur dan memanjang ujungnya runcing. Pangkalnya membulat helaian daun besar, tepinya berlekuk dan helaian yang lebih kecil bergerigi. Buah bunganya bertangkai, warnanya kuning, berdaging, kulitnya tipis dan licin mengkilat, beragam dalam bentuk maupun ukurannya, warnanya merah atau kuning hijau. Bijinya banyak berwarna kuning coklat. Berkhasiat untuk pengobatan penyakit jerawat. Bagian tanaman yang dimanfaatkan adalah bunga tomat. Cara pengolahannya adalah buah tomat yang telah masak diiris kecil-kecil kemudian digosokkan pada muka yang berjerawat selama 1-2 kali sehari.

Jenis tanaman yang ditemukan tumbuh banyak di ketiga lokasi penelitian karena disesuaikan dengan tempat tumbuhnya masing-masing yaitu ada yang tumbuh di dataran rendah dan di dataran tinggi. Daerah dataran rendah adalah daerah yang cocok untuk pertumbuhan jenis tanaman dari famili Caesalpiniceae, Zingiberaceae, Myrtaceae, Arecaceae, Apocynaceae, Solanaceae, Liliaceae, Moraceae, Cariccaceae, Piperaceae, dan Malvaceae, sedangkan di daerah dataran tinggi termasuk juga daerah yang baik untuk ditanami oleh jenis tanaman dari famili Zingiberaceae, Arecaceae, Solanaceae, dan Cariccaceae (Hembing, 1993;Tampubolon, 1995; Fauzan, 1996). Menurut Sugeng (1984) tipe daratan yang sesuai untuk pertumbuhan jenis tanaman terdapat pada famili Zingiberaceae dan Cariccaceae yang bisa tumbuh pada daerah dataran rendah dan dataran tinggi.

Jenis tanaman yang ditemukan tumbuh di ketiga Kelurahan itu dapat dikategorikan memiliki keanekaragaman yang tinggi. Hal ini disebabkan karena ketiga lokasi tersebut memiliki tanah yang gembur (tidak kering) dan mudah ditanami oleh berbagai jenis tanaman apa saja, serta memiliki keanekaragaman jenis tanaman obat tradisional yang berkhasiat untuk pengobatan penyakit kulit. Dari keseluruhan jenis tanaman yang telah ditemukan keberadaannya pada lingkungan tersebut, namun ada beberapa yang tidak ditemukan tetapi masih satu Kelurahan.

Hasil inventarisasi jenis tanaman yang telah ditemukan di tiga lokasi penelitian bahwa diantara ketiga Kelurahan itu hanya Kelurahan Sasa yang memiliki jumlah tanaman lebih banyak dibandingkan yang berada di Kelurahan Jambula dan Kastela. Jenis tanaman yang ditemukan tumbuh subur di pekarangan rumah, kebun, pinggir jalan dan pesisir pantai. Jenis-jenis tanaman obat tradisional tersebut ditanam oleh masyarakat setempat selain sebagai tanaman obat, ada juga dipergunakan sebagai bumbu dapur, tanaman hias, tanaman buah dan adapula berupa tanaman liar yang tumbuh liar.

Hasil wawancara terbuka di masyarakat tiga Kelurahan tersebut bahwa jenis tanaman yang telah ditemukan telah banyak digunakan oleh masyarakat sebagai obat tradisional untuk pengobatan penyakit kulit dan tanaman yang sering dipergunakan oleh masyarakat setempat 
sebagai obat tradisional diantaranya Carica papaya (pepaya) dan Lycopersicon esculentum Mill. (tomat) sebagai obat jerawat, Languas galangga (lengkuas) sebagai obat panu, Psidium guajava (jambu biji) sebagai obat luka berdarah, Curcuma domestica (kunyit) sebagai obat cacar air, Brugmansia suaveokens (kecubung hutan) sebagai obat eksim dan Piper betle L. (sirih) sebagai obat gatal-gatal pada kulit.

\section{KESIMPULAN}

Dari hasil inventarisasi jenis tanaman obat tradisional yang berkhasiat untuk pengobatan penyakit kulit yang telah ditemukan, maka dapat menarik kesimpulan bahwa ; Jenis tanaman obat tradisional yang berkhasiat yang berkhasiat untuk pengobatan penyakit kulit yang terdapat di tiga Kelurahan sebanyak 15 jenis dengan 11 famili. Pada umumnya masyarakat setempat lebih cenderung menggunakan jenis tanaman itu sebagai obat tradisional khususnya untuk pengobatan penyakit kulit.

\section{DAFTAR REFERENSI}

Fauzan, M. 1996. Tanaman Obat Keluarga. PT. Penebar Swadaya. Jakarta.

Gunawan, Djoko. 1990. Ramuan Tradisional Untuk Penyakit Kulit. Penebar Swadaya. Jakarta.

Hembing, W. H. M. dkk, 1993. Tanaman berkhasiat Obat di Indonesia. Jilid ke 3. Pustaka Kartini. Jakarta.

Mamahani, Angela F, and Herny E I Simbala. 2016. "Etnobotani Tumbuhan Obat Masyarakat Subetnis Tonsawang Di Kabupaten Minahasa Tenggara Provinsi Sulawesi Utara." PHARMACONJurnal Ilmiah Farmasi 5 (2): 205-12.

Sugeng, H. R. 1984. Tanaman Apotik Hidup. PT. Aneka Ilmu. Semarang

Tamalene, M Nasir, M.I. Al Muhadar, Henie, Endang Suarsini, and Fatchur Rohman. 2016. "Study of Ethnobotany of Medicinal Plant of Tobelo Dalam (Togutil) Ethnic Group of Halmahera Island , Indonesia." Medical Plant- International Journal of Phytomedicines and Related Industries 8 (2): 127-36. https:// doi.org/10.5958/0975-6892.2016.00016.2.

Tampubolon, O. T. 1995. Tumbuhan Obat. PT. Bratara. Jakarta.

Wiryohadikusumo. 1999. Obat Kuno Mujarab. Penerbit Anugrah. Surabaya. 